\title{
Tracking Internal Auditor Salaries: Information From Twenty-One Years Of Research
}

Jimie Kusel, University of Arkansas at Little Rock

Cynthia Taylor, University of Arkansas at Little Rock

\begin{abstract}
This research tracks from 1985 through 2006 salaries and other characteristics of the internal auditing function in the United States. Prior to 1985, the Institute of Internal Auditors, Inc. (IIA) had no formal way of determining salary levels for internal auditors and providing such data for use in field audit offices. A survey instrument was designed to obtain salaries and other job market information. The IIA approved the survey instrument and sent it on a biannual basis to the more than 3000 internal auditing directors who were members of the IIA. This paper provides tables that track mean level audit director salaries, staff level auditor salaries, and auditor salaries in selected industries and regions of the country through 2006. Causes for differences in gender salaries are explored. The paper comments on research findings using the 1990 and 2000 salary data. That research indicates that overall national statistics may distort gender comparisons of salary levels because adequate attention is not usually given to type of organization, size of organization, and level of director experience. Salaries for directors, staff level positions, and within selected industries are tracked against the consumer price index and tables indicate the extent to which the profession has maintained pace. The research indicates that high staff turnover rates combined with more female than male graduates in accounting are currently changing the gender composition of the profession. At the entry staff level in 2006 there were more women than men hired. Despite all of the changes in the profession, a majority of the auditors believe their salary is fair, that they are treated as a valued consultant, and would recommend an internal auditing career.
\end{abstract}

Key Words: internal auditor, Sarbanes-Oxley Act, internal auditor compensation, gender inequity in compensation, internal auditor work environment.

\section{INTRODUCTION}

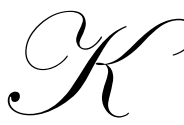

eeping tabs on the job market is usually part of every professional's agenda. Even for those in comfortable, "tailor-made" slots, it's important to know what forces are influencing their jobs, and how their situations compare to others. This is certainly true for professionals in internal auditing. For the past twenty-one years bi-annual national surveys of the internal auditing profession originated and designed in 1985 by Dr. Jimie Kusel and Dr. Tom Oxner, have been administered by the Institute of Internal Auditors (IIA). The resulting survey findings, supplemented by related research by the IIA and others, provide a unique look into the nature and operation of the profession.

A proper understanding of salary amounts and salary trends requires background information about job market conditions of the internal auditor. This paper begins with a brief description of services performed by the internal auditor and of the workplace. The qualifications of those who have and are now occupying the director and staff positions are discussed. Staff turnover rates and the gender composition of internal auditing staffs are reviewed. Considerable information is provided on the trend in salaries. The issue of gender equity in pay is addressed. 
Job market survey data in the United States for the years 1985 thru 2002 were obtained solely from directors or chief internal auditing executives. The 2004 and 2006 job market surveys were sent to internal auditors at various levels of the profession. Some results from these surveys are not, therefore, directly comparable to previous survey data. Data provided in the 2004 and 2006 columns of the following tables were obtained or derived from applicable portions of these job market surveys, from additional survey data provided by the IIA available on their website: www.gain2.org, and from the Assistant Vice-President of Online Services at IIA who monitors IIA's Global Auditing Information Network (GAIN) programs. The number of directors responding to each of the national surveys ranged from about 600 to over 2000 .

\section{THE INTERNAL AUDITING ENVIRONMENT}

Describing the specific services an internal auditor may perform for management at a given location is difficult. These services depend upon the needs of management which may differ between industries and even among companies in the same industry. The principal services that an internal auditor may perform for an organization are listed by James Hooper, past board chairman of the Institute of Internal Auditors (IIA).

- $\quad$ Reviews and evaluates operations and services as decision support to management.

- $\quad$ Advises management whether established policies, procedures, laws and regulations are being observed.

- $\quad$ Reviews systems in internal accounting control and provides assurance against costly and embarrassing failures.

- Helps ensure that EDP installations and computer systems are efficient, fraud-resistant and capable of recovering from disaster.

- $\quad$ Reviews contracts and projects and promotes the organization's rightful interest in dealings with outside vendors, contractors and joint-venture participants.

- $\quad$ Provides valuable assistance in the deterrence and detection of fraud.

- Provides liaison with the external auditors and advises senior management and the board of directors, concerning the quality of their services.

Since the economic collapse of such giant corporations as WorldCom and Enron there has been an intense focus by the public on the reliability of reported financial data. This places renewed emphasis on the review of internal controls listed in the above services.

The Sarbanes-Oxley Act of 2002 ushered in sweeping changes to the accounting profession that directly influenced the activities of many internal auditors. This act does not specifically address the role of internal auditors. It is reasonable to conclude, however, that as long as the internal auditors ensure that the work they perform does not impair the objectivity of the internal auditing activity, providing support to management is a legitimate role for them to fulfill.

The national survey of the internal auditing job market completed in 2000 provided considerable insight into the workplace of the internal auditor (Kusel, 2000). That survey disclosed that about 50 percent of all internal auditing staffs consist of 4 or fewer internal auditors. About 90 percent of the staffs consist of 20 auditors or less. Unlike in public accounting, there is no uniformity in position titles between internal auditing staffs. Typically, one will find the positions of staff auditor, audit manager or supervisor, and director of internal auditing.

The academic credentials of directors of internal auditing were not tracked consistently since it became evident that by 1990 most all directors held some type of academic degree. The 2004 job market survey disclosed that approximately 95 percent of all responding internal auditors at all levels of management held an undergraduate degree (Oxner, 2004). About 32 percent held a master's degree, a sought after degree for today's top notch internal auditing staffs (Harrington, 2004).

A growing percentage of directors have earned their certification as a public accountant (CPA). Since 1999 the percentage of directors awarded CPA certifications has increased from 48.4 percent in 1990 to 58.9 percent in 
2004. Certified internal auditor (CIA) certifications are held by a smaller percentage of directors ranging from 27.0 percent in 1990 to 33.8 percent in 2004 according to the Assistant Vice-President for Online Services at the IIA.

The 2002 job market survey determined that on average directors of internal auditing have 15.9 years experience working in auditing and 5.5 years of experience in the position of director (Kusel, 2002).

From 1990 through 2002 about 25 percent of staff auditors held a CPA certification and slightly less than 15 percent were certified internal auditors. The 2004 job market survey did not determine staff certifications.

These qualifications produce competent internal auditing professionals who bring to the table objectivity, integrity, expertise in communication, the ability to identify enterprise risks, and the skill to assess the effectiveness of controls put in place by management.

In the bi-annual national surveys conducted from 1992 to 2002 internal auditing directors were asked to indicate if they expected their authorized staff size to stay the same, increase, or to decrease. As shown in Table 1, these surveys indicated that in 1992 about 25 percent of internal auditing directors expected to gain more internal auditing positions. The economic downturn in $1994-2002$, however, resulted in a decrease in these percentages. The economic upturn combined with requirements of the Sarbanes-Oxley Act of 2002 and the NYSE requirements for all companies to have an internal auditing function increased the demand for internal auditors after 2002.

The Assistant Vice President for Online Services at IIA believes the new median number of auditors on a staff will rise from four in 2002 to over five by 2006.

Table 1

The Trend In Staff Size

\begin{tabular}{|c|c|c|c|c|c|c|}
\hline & $\mathbf{1 9 9 2}$ & $\mathbf{1 9 9 4}$ & $\mathbf{1 9 9 6}$ & $\mathbf{1 9 9 8}$ & $\mathbf{2 0 0 0}$ & $\mathbf{2 0 0 2}$ \\
\hline Remain Unchanged & 67.9 & 72.5 & 74.8 & 76.1 & 76.3 & 78.6 \\
\hline Increase & 23.6 & 19.8 & 19.4 & 20.6 & 19.7 & 15.7 \\
\hline Decrease & 8.5 & 7.7 & 5.8 & 3.3 & 4.1 & 5.7 \\
\hline
\end{tabular}

Job vacancies on the internal auditing staff are created by a high departure rate of staff auditors. In 2004, for example, 66.9 percent of internal auditors left the staff within four years. A very high 89.4 percent of internal auditors left the staff within six years (Oxner, 2004). Departure rates for staff internal auditors for the years 19922002 are provided in Table 2:

Table 2

Yearly Comparisons of Departure Rates 1992-2002

\begin{tabular}{|c|c|c|c|c|c|c|}
\hline Years & $\mathbf{1 9 9 2}$ & $\mathbf{1 9 9 4}$ & $\mathbf{1 9 9 6}$ & $\mathbf{1 9 9 8}$ & $\mathbf{2 0 0 0}$ & $\mathbf{2 0 0 2}$ \\
\hline $0-2$ & 16.7 & 10.5 & 10.7 & 10.0 & 15.2 & 13.4 \\
\hline $3-4$ & 48.7 & 45.1 & 42.8 & 36.3 & 41.5 & 42.3 \\
\hline $5-6$ & 21.3 & 26.8 & 25.6 & 29.4 & 21.2 & 24.1 \\
\hline $7-10$ & 9.4 & 10.2 & 13.0 & 13.7 & 12.5 & 11.2 \\
\hline$>10$ & 3.9 & 7.4 & 8.4 & 10.6 & 9.6 & 9.0 \\
\hline
\end{tabular}

The surveys disclosed that staff departure rates are often influenced by the opportunity to move into higher level management positions. Over all twenty-six years of these surveys, more than 90 percent of internal auditing directors have reported that internal auditing staff work provides experience for higher level positions. 
In general, the larger the internal auditing staff, the more likely the director considers the internal auditing department as a training ground for future managers. In 2002, 37.7 percent of directors of one or two-person audit offices said that management uses internal auditing as a stepping stone job. More than half (57.7 percent) of the directors with staffs of more than 10 internal auditors said that the auditing department is used to train future managers. The 2006 survey did not stratify internal auditing staff by size, and reported an overall 45 percent of respondents agreeing that the internal auditing function is used as a training area (Oxner, 2006).

\section{GENDER COMPOSITION}

An increasing percentage of women are now found on internal auditing staffs and in the director position. As Table 3 indicates, in 1990 women occupied 31.6 percent of staff-level positions (Kusel, 1990). That total has grown to 44.5 percent in 2006. And indeed, the 2006 survey reports for the first time that females in the United States comprised over half (57.1 percent) of new staff personnel (Oxner, 2006). These trends, as can be seen in Table 3, are pervasive in the manufacturing sector as well as in selected industries in the non-manufacturing sector.

Thirty-five years ago female accounting majors in universities were rare. By 1978, the first year the AICPA surveyed schools producing accounting graduates, only 28 percent of the graduates were female. By 1988 the percentage of female graduates in accounting exceeded the percentage of male graduates for the fist time. Today, more than half of graduates with a degree in accounting are female (AICPA, 1992).

Concurrent with the rise in the percentage of internal auditing positions occupied by women is the rise of the percentage of women that occupy the director's position.

Table 3

Percentage Of Women On Staff

\begin{tabular}{|c|c|c|c|c|c|}
\hline & $\mathbf{1 9 9 0}$ & $\mathbf{1 9 9 2}$ & $\mathbf{1 9 9 8}$ & $\mathbf{2 0 0 2}$ & $\mathbf{2 0 0 6}$ \\
\hline United States & 31.6 & 37.9 & 36.3 & 44.1 & 44.5 \\
\hline All Manufacturing & 29.9 & 24.2 & 29.6 & 34.1 & -- \\
\hline Education & 41.1 & 34.5 & 47.1 & 51.6 & -- \\
\hline Financial/Banking & 38.8 & 47.9 & 44.7 & 45.3 & -- \\
\hline Health Care & 42.1 & -- & 53.1 & 59.1 & - \\
\hline Public Utilities & 29.8 & -- & -- & 39.6 & -- \\
\hline
\end{tabular}

As Table 4 shows, the percentage of female directors of internal auditing has increased. Overall in the United States from 15.5 percent in 1990 to 40.7 percent in 2006. Again, these percentage increases are consistent throughout all economic sectors of the economy.

Table 4

Percentage Of Women That Are Directors Of Internal Auditing

\begin{tabular}{|c|c|c|c|c|c|}
\hline \multicolumn{7}{|c|}{ Years } \\
\hline & $\mathbf{1 9 9 0}$ & $\mathbf{1 9 9 2}$ & $\mathbf{1 9 9 8}$ & $\mathbf{2 0 0 2}$ & $\mathbf{2 0 0 6}$ \\
\hline United States & 15.5 & 18.1 & 23.4 & 30.2 & 40.7 \\
\hline All Manufacturing & 8.3 & 7.4 & 8.9 & 21.3 & -- \\
\hline Education & 25.4 & 27.3 & 34.5 & 37.5 & -- \\
\hline Financial/Banking & 20.3 & 24.9 & 26.1 & 29.7 & -- \\
\hline Health Care & 23.4 & 28.3 & 24.1 & 37.0 & - \\
\hline Public Utilities & 9.8 & 15.7 & 25.0 & 23.5 & -- \\
\hline
\end{tabular}

As shown in Table 5, the mean base salary (excluding bonuses) of the director has risen from $\$ 45,000$ in 1985 to $\$ 110,000$ in 2006. 
Despite forces on job security in the decade of the 90's brought about by right sizing, outsourcing and reengineering, salaries have continued to increase. The 1990's opened with double digit percentage increases in salaries for both the director and staff level positions. Percentage increases in salary levels generally slowed during the 1992-2000 time frame before rebounding back into the double digit category.

Table 5 provides for the years 1985 thru 2006, as available, the mean director and staff level salaries. The staff level salaries are stratified by selected industries and by regions of the country. The mean salary level for staff auditors are for those auditors in the three to four year experience category. The majority of staff level auditors fall within that experience level.

Table 5

Mean Director and Staff Level Salaries

(in thousands)

\begin{tabular}{|l|c|c|c|c|c|c|c|c|c|c|c|}
\hline & $\mathbf{1 9 8 5}$ & $\mathbf{1 9 8 8}$ & $\mathbf{1 9 9 0}$ & $\mathbf{1 9 9 2}$ & $\mathbf{1 9 9 4}$ & $\mathbf{1 9 9 6}$ & $\mathbf{1 9 9 8}$ & $\mathbf{2 0 0 0}$ & $\mathbf{2 0 0 2}$ & $\mathbf{2 0 0 4}$ & $\mathbf{2 0 0 6}$ \\
\hline Director & 45.0 & 51.3 & 62.9 & 63.0 & 73.8 & 72.6 & 78.9 & 81.7 & 92.4 & 93.2 & 110.0 \\
\hline & & & & & & & & & & & \\
\hline Staff: & & & & & & & & & & & \\
\hline & & & & & & & & & & & \\
\hline Overall & 24.0 & 29.4 & 32.6 & 32.6 & 35.5 & 35.9 & 37.8 & 41.2 & 46.3 & 47.9 & 51.7 \\
\hline & & & & & & & & & & & \\
\hline Industry: & & & & & & & & & & & \\
\hline All Manufacturing & 26.5 & 31.4 & 35.3 & 37.0 & 38.7 & 39.5 & 41.4 & 46.1 & 54.0 & 51.9 & -- \\
\hline Education & 21.5 & 26.9 & 30.2 & 31.3 & 32.1 & 31.9 & 32.9 & 39.7 & 41.9 & -- & -- \\
\hline Financial/Banking & 21.6 & 26.3 & 29.5 & 29.9 & 32.8 & 31.3 & 35.0 & 36.7 & 42.2 & 43.2 & 48.9 \\
\hline Government & 23.5 & 28.2 & 32.0 & 33.4 & 34.2 & 33.6 & 34.6 & 36.1 & 42.4 & 50.5 & -- \\
\hline Health Care & 23.5 & 28.9 & 32.0 & 33.4 & 35.4 & 35.8 & 42.1 & 43.2 & 47.2 & 44.9 & 51.7 \\
\hline Insurance & 23.6 & 29.2 & 32.2 & 32.3 & 35.1 & 36.8 & 40.3 & 41.9 & 47.2 & 46.1 & 50.8 \\
\hline Public Utilities & 27.2 & 31.5 & 34.3 & 35.9 & 39.4 & 40.4 & 45.5 & 46.0 & 50.5 & 55.9 & 56.7 \\
\hline & & & & & & & & & & & \\
\hline Region: & & & & & & & & & & & \\
\hline Northeastern & 23.7 & 32.0 & 33.8 & 34.1 & 37.8 & 35.8 & 37.0 & 45.8 & 47.8 & -- & -- \\
\hline Eastern & 21.7 & 29.6 & 33.0 & 32.2 & 34.9 & 36.4 & 36.7 & 40.8 & 45.8 & -- & -- \\
\hline Southeastern & 21.5 & 27.7 & 31.5 & 30.5 & 34.3 & 34.4 & 36.8 & 38.5 & 45.0 & -- & -- \\
\hline Central & 21.7 & 27.9 & 31.9 & 32.3 & 34.9 & 34.5 & 37.4 & 39.7 & 47.6 & -- & -- \\
\hline Midwestern & 22.9 & 29.3 & 31.7 & 31.8 & 35.2 & 35.2 & 36.9 & 41.7 & 43.6 & -- & -- \\
\hline Southern & 22.0 & 29.1 & 32.4 & 32.2 & 33.2 & 35.0 & 35.9 & 38.9 & 44.4 & -- & -- \\
\hline Northwestern & 27.3 & 31.4 & 33.5 & 33.1 & 36.3 & 39.6 & 39.4 & 42.3 & 46.4 & -- & -- \\
\hline Southwestern & 27.4 & 30.9 & 33.8 & 35.4 & 38.1 & 40.5 & 42.6 & 43.9 & 51.9 & -- & -- \\
\hline
\end{tabular}

As a review of data in Table 5 indicates, average staff level salaries are not the same across industries or regions of the country. Within industries, all manufacturing and public utilities have consistently offered higher salaries. The education and financial/banking industries have consistently paid less. There is no clear pattern of salary levels within the regions, however, the highest staff salaries tend to cluster in the Northeastern, Northwestern, and Southwestern sectors of the country. The research indicates that director level salaries follow the same pattern.

Using 1985 as a base year, Table 6 provides a comparison of the percentage increases in salary levels with the percentage increase in the consumer price index (CPI). Director level salaries have outpaced increases in the consumer price index in all years. Staff level salaries have generally kept pace with the index. One may conclude that the purchasing power of salaries within the internal auditing profession has been maintained. 
Table 6

Consumer Price Index, Director Salaries, and Staff Level Salaries:

Percentage Increase from Base Year 1985 to 2006

\begin{tabular}{|c|c|c|c|c|c|c|c|c|c|c|c|}
\hline & 1985 & 1988 & 1990 & 1992 & 1994 & 1996 & 1998 & 2000 & 2002 & 2004 & 2006 \\
\hline CPI & -- & 10.7 & 23.1 & 32.7 & 40.6 & 49.3 & 55.4 & 64.6 & 72.3 & 81.3 & 94.0 \\
\hline Director & -- & 14.0 & 39.7 & 40.0 & 64.0 & 61.3 & 75.3 & 81.5 & 105.3 & 107.1 & 144.4 \\
\hline \multicolumn{12}{|l|}{ Staff: } \\
\hline & & & & & & & & & & & \\
\hline Overall & -- & 22.5 & 35.8 & 35.8 & 47.9 & 49.5 & 57.5 & 71.6 & 92.5 & 99.6 & 115.4 \\
\hline & & & & & & & & & & & \\
\hline \multicolumn{12}{|l|}{ Industry: } \\
\hline All Manufacturing & -- & 18.4 & 33.2 & 39.6 & 46.0 & 49.0 & 56.2 & 73.9 & 103.7 & 95.8 & -- \\
\hline Education & -- & 25.1 & 40.4 & 45.5 & 49.3 & 48.3 & 53.0 & 84.6 & 93.9 & -- & -- \\
\hline Financial/Banking & -- & 21.7 & 36.5 & 38.4 & 51.8 & 44.9 & 62.0 & 69.9 & 95.3 & 100.0 & 126.3 \\
\hline Government & -- & 20.0 & 36.1 & 42.1 & 45.5 & 42.9 & 47.2 & 53.6 & 80.4 & 114.9 & -- \\
\hline Health Care & -- & 22.9 & 36.1 & 42.1 & 50.6 & 52.3 & 79.1 & 83.8 & 100.8 & 91.1 & 120.0 \\
\hline Insurance & -- & 23.7 & 36.4 & 36.8 & 48.7 & 55.9 & 70.7 & 77.5 & 100.0 & 95.3 & 115.3 \\
\hline Public Utilities & -- & 15.8 & 26.1 & 31.9 & 44.8 & 48.5 & 67.2 & 69.1 & 85.6 & 105.5 & 108.5 \\
\hline \multicolumn{12}{|l|}{ Region: } \\
\hline Northeastern & -- & 35.0 & 42.6 & 43.8 & 59.4 & 51.0 & 56.1 & 93.2 & 101.6 & -- & -- \\
\hline Eastern & -- & 36.4 & 52.0 & 48.3 & 60.8 & 67.7 & 69.1 & 88.0 & 111.0 & -- & -- \\
\hline Southeastern & -- & 28.8 & 46.5 & 41.8 & 59.5 & 60.0 & 71.1 & 79.0 & 109.3 & -- & -- \\
\hline Central & -- & 28.5 & 47.0 & 48.8 & 60.8 & 58.9 & 72.3 & 82.9 & 119.3 & -- & -- \\
\hline Midwestern & -- & 27.9 & 38.4 & 38.8 & 53.7 & 53.7 & 61.1 & 82.0 & 90.3 & -- & -- \\
\hline Southern & -- & 32.2 & 47.2 & 46.3 & 50.9 & 59.0 & 63.1 & 76.8 & 101.8 & -- & -- \\
\hline Northwestern & -- & 15.0 & 22.7 & 21.2 & 32.9 & 45.0 & 44.3 & 54.9 & 69.9 & -- & -- \\
\hline Southwestern & -- & 12.7 & 23.3 & 29.1 & 39.0 & 47.8 & 55.4 & 60.2 & 89.4 & -- & -- \\
\hline
\end{tabular}

\section{SALARIES OF MALE AND FEMAL DIRECTORS}

Many of the explanations for the difference in male and female compensation and advancement in the accounting profession are based upon labor market discrimination theories (Brown, 1998). Prior research asserts that the restricted advancement of women in the accounting profession is due to gender bias, and the social, cultural, and political climate of the employing organizations and the profession (Coutts and Roberts, 1995; Jackson and Hirsh, 1991; Shearer and Arrington, 1993).

Studies have shown that although women posses equal formal qualifications to men upon entry to the accounting profession, pressures within the profession lead to differences in career progression between men and women and the steering of women towards lower status and lower paid position (Boyer, 1995; Shearer and Arrington, 1993).

Mean director salaries by gender for the selected year of 1990 and 2000 are shown in Table 7 . The table shows that male director salaries increased, on average, 29.5 percent over the ten-year period, while female director salaries increased 48.3 percent. Male salaries, however, have remained consistently higher than female salaries. In 1990 the average male director salary in the United States was $\$ 65,400$. By 2000 the average salary had reached $\$ 84,700$. By contrast, mean salaries for female directors were $\$ 49,300$ in 1990, and $\$ 73,100$ in 2000 . 
Table 7

Mean Director Salaries by Gender 1990-2000

\begin{tabular}{|c|c|c|c|c|c|c|}
\hline & \multicolumn{3}{|c|}{1990} & \multicolumn{3}{|c|}{2000} \\
\hline & Male & Female & $\begin{array}{l}\text { Female as } \\
\% \text { of Male }\end{array}$ & Male & Female & $\begin{array}{l}\text { Female as } \\
\% \text { of Male }\end{array}$ \\
\hline United States & 65,400 & 49,300 & 75.4 & 84,700 & 73,100 & 86.3 \\
\hline Canada & 63,600 & 59,800 & 94.0 & 86,200 & 77,400 & 89.9 \\
\hline All Manufacturing & 76,900 & 52,800 & 68.7 & 94,100 & 94,600 & 100.5 \\
\hline Financial Banking & 61,100 & 46,000 & 75.3 & 81,900 & 67,100 & 81.9 \\
\hline Education & 54,600 & 46,100 & 84.4 & 77,700 & 63,800 & 82.1 \\
\hline Health Care & 58,600 & 49,200 & 84.0 & 88,600 & 67,800 & 76.5 \\
\hline Public Utilities & 70,000 & 50,900 & 72.7 & 88,300 & 86,400 & 97.9 \\
\hline
\end{tabular}

Research data was used to examine the possibility of a gender inequity in salaries in 1994 and again in the year 2000. The hypothesis was that organizational factors such as: (1) the size of the director's staff, (2) the type of employing organization, and (3) the experience level of the director may affect the compensation of directors of internal auditing. Table 8 shows for the year 2000 the percent of male and female directors that manage a given staff size and the mean salary levels associated with staff size. The data indicate that male directors manage a higher proportion of the higher paying large offices. This distribution of male and female directors of internal auditing may explain some of the average difference in compensation at the director position (Taylor, 2002).

Table 8

Mean Director Salaries by Size of Auditing Staff 2000

\begin{tabular}{|c|c|c|c|c|c|}
\hline \multirow{2}{*}{$\begin{array}{c}\text { Staff } \\
\text { Size }\end{array}$} & \multicolumn{2}{|c|}{ Male } & \multicolumn{2}{|c|}{ Female } & Female as \% of \\
\cline { 2 - 6 } Male
\end{tabular}

As observed in Table 5 above, the type of organization also affects compensation. A smaller-percentage of women directors of internal auditing are found in the higher paying industries. For example, in the year 2000, thirteen percent of all male directors were associated with manufacturing operations, while only about six percent of female directors were associated with manufacturing operations.

An additional factor influencing salary levels is the experience level of the director. Experience can be measured in terms of (1) the number of years in auditing, and (2) the number of years served as director of internal auditing (Kusel, 1996). Table 9 provides a comparison of male and female experience levels for the years 1990 and 2000. Female director experience is expressed as a percentage of male director experience. Since 1990, almost without exception, male directors of internal auditing have had more years of experience in auditing and have served more years as director than their female counterparts. These differences in experience levels contribute to the differences in gender salary levels. A comparison of 1990 and 2000 data indicates that the experience level gap is narrowing, and therefore, explains in part, the narrowing of the compensation gap over the ten-year period. 
Table 9

Female Director as a Percentage of Male Director Experience Levels

\begin{tabular}{|c|c|c|}
\hline Measure & \multicolumn{2}{|c|}{ Years } \\
\hline Number of Years in Auditing & 1990 & 2000 \\
\hline United States & 63.3 & 73.9 \\
\hline All Manufacturing & & 74.9 \\
\hline Financial/Banking & 44.4 & 78.2 \\
\hline Education & 72.3 & 69.4 \\
\hline Health Care & 62.8 & 73.3 \\
\hline Public Utilities & 53.3 & 87.2 \\
\hline \multicolumn{2}{|c|}{} & 2000 \\
\hline Number of Years as Director & 77.2 & 80.6 \\
\hline United States & 1990 & 44.7 \\
\hline All Manufacturing & 67.3 & 85.3 \\
\hline Financial/Banking & 27.1 & 83.6 \\
\hline Education & 73.6 & 69.2 \\
\hline Health Care & 59.4 & 127.5 \\
\hline
\end{tabular}

A regression analysis of the 1990-2000 data is provided in Table 10 (Kusel, 2005).

Table 10

Model: Compensation $=a+\beta_{1}$ Staff Size $+\beta_{2}$ Gender $+\beta_{3}$ Years in Auditing $+\beta_{4}$ Years in Current Position $+\beta_{5}$ Sector $+e$

\begin{tabular}{|c|c|c|c|}
\hline Variable & Coefficient & t-statistic & Significance \\
\hline Constant & 75295.015 & 13.064 & .000 \\
\hline Staff Size & .139 & 3.121 & $.002^{*}$ \\
\hline Gender & -.082 & -1.845 & .064 \\
\hline Years in Auditing & .106 & 2.013 & $.045^{*}$ \\
\hline Years in Current Position & -.070 & -1.376 & .169 \\
\hline Economic Sector & .166 & 3.840 & $.000^{*}$ \\
\hline
\end{tabular}

*Significant at alpha $=.05$

Adjusted R Square $=.10$

Of the variability explained by the model, the coefficients indicate that the sector in which the organization operates contributes the most to explaining the difference in male and female salaries. The size of the internal audit staff and the number of years spent in auditing are also statistically significant at the .05 level of significance. Directors who supervise larger staff sizes are compensated more than those who supervise smaller staff sizes. The number of years in auditing is negatively related to compensation, which indicates some salary inversion at the director position or that higher compensation is a function of the organization type and staff size, not the level of experience in auditing. More importantly, gender does not appear to contribute significantly to the difference in salaries of male and female directors of internal auditing in this or in the original 1994 study.

This much can be said about a possible gender gap in director salaries. Overall national statistics distort gender comparisons of salary levels because adequate attention is not usually given to type of organization, size of organization, and level of director experience. As the current study indicates, female directors of internal auditing are found in all levels of all types of organizations, but they are often located in lower paying organizations, heading smaller staffs, and with less experience than their male counterparts. 


\section{ABOUT THE AUTHORS}

Jimie Kusel is a professor of accounting at the University of Arkansas at Little Rock. He received his AB from Princeton University and the Ph.D. from Michigan State University. He is a former Director of Research for the Air Force Internal Audit Agency and processed data for IIA's bi-annual job market surveys for twenty years.

Cynthia Taylor is an associate professor of accounting at the University of Arkansas at Little Rock. She received her Ph.D. from Oklahoma State University. She has made presentations on and written several articles concerning the internal auditing profession.

\section{CONCLUSION}

The duties and salaries of internal auditors are affected by such factors as type industry in which employed sector of the country, size of the internal auditing staff, and experience level. Salaries within the profession have generally out paced increases in the consumer price index.

There are signs that there is a growing acceptance of women in the internal auditing profession. If bias toward the employment of women exists, at least trends are in the proper direction. And of equal significance, women as well as men are proving they can reach the top.

The ultimate test of a profession may be the attitude of the workers. From 1985 to the present, more than 60 percent of both men and women have responded that their salary was fair, that they were treated as a valued consultant, and that they would recommend internal auditing work as a career.

\section{REFERENCES}

1. $\quad$ AICPA, The Supply of Accounting Graduates and the Demand for Public Accounting Recruits 1992 p. 12.

2. $\quad$ Boyer, I., 1995, Women's Careers in Accounting CIMA Publishing, London.

3. Brown, Rhoda. 1998, An Application of Human Capital Theory to Salary Differentials in the Accounting Profession. Women in Management Review. Vol. 13, no. 5. pp. 192-200.

4. Coutts, J. A. and J. Roberts. 1995. Segregation: A Patriarchal Strategy in the Professions. Advances in Public Interest Accounting, no. 6, pp. 99-131.

5. Harrington, C., Internal Audit's New Role, Journal of Accountancy September 2004, pp. 65-70.

6. Jackson, C. and W. Hirsh. 1991. Women Managers and career Progression. The British Experience, Women in Management Review (UK) vol. 6, no. 2, pp. 10-16.

7. Kusel, J. and T. Oxner, The Internal Auditor Job Market 1990. The Institute of Internal Auditors 1990, 255 pages.

8. Kusel, J. and T. Oxner, The Internal Auditor Job Market 1996. The Institute of Internal Auditors 1996, 220 pages.

9. Kusel, J. and T. Oxner, The Internal Auditor Job Market 2000. The Institute of Internal Auditors 2000, 199 pages.

10. Kusel, J. and T. Oxner, The Internal Auditor Job Market 2002, The Institute of Internal Auditors 2002, 217 pages.

11. Kusel, J. and T. Oxner, C.L. Taylor, and K. Oxner, Twenty Years of Changes and Trends Within the Internal Auditing Profession, The International Journal of Business and Public Administration, vol. 2, November 2, Fall 2005, pp. 76-85.

12. Oxner T. and K. Ovner, A Good Time to Be an Internal Auditor, Internal Auditor June 2004, pp. 58-65.

13. Oxner, T. and K. Oxner, For Internal Audit Professionals, Internal Auditor June 2006, pp. 51-57.

14. Shearer, T. and C. Arrington. 1993 Accounting in Other Worlds. A Feminism Without Reserve. Accounting Organization and Society, vol. 18, no. 2/3, pp. 253.

15. Teylor, C.L., T. Oxner, J. Kusel, D.E. Edwards, 2002 Internal Audit Moves Toward Gender Equity, Journal of Accounting and Finance Research, , vol. 10, no. 4, pp. 11-17. 
NOTES 